\title{
Ecological Implications and Source Apportionment of Heavy Metal and Hydrocarbon Contaminants in the Soil of a Poorly Crude Oil Remediated Site in Nigeria: A Case of Ikot Ada Udo Community
}

\author{
Akaninyene Joseph ${ }^{1 *}$, Udeme Udofia', Uwem Edet ${ }^{2}$, \\ Eno Iwok', Vivian Ivara' \\ 1 Department of Zoology and Environmental Biology, Faculty of Biological Sciences, University of Calabar, \\ Calabar, Cross River State, Nigeria \\ 2 Department of Biological Science, Faculty of Natural and Applied Sciences, Arthur Jarvis University, Akpabuyo, \\ Cross River State, Nigeria \\ * Corresponding author's e-mail: joseph.akan@yahoo.com
}

\begin{abstract}
The ecological risk and source apportionment of heavy metals and hydrocarbons in soil from the study site was carried out. Composite soil samples $(n=48)$ were collected from 3 sampling points (SP 1, SP 2, SP 3$)$ within the site at 50, 200, and 500 meters, respectively, from the oil well and from a control site (Ibagwa, Abak) at 10,000 meters from the study site, using a hand-held auger. The samples were analyzed for heavy metals using inductively coupled plasma atomic emission spectrometry (ICP-AES, Yobin Yvon JY-24) and total petroleum hydrocarbon (TPH) using Agilent 6890N Gas Chromatography - Flame Ionization Detector (GC- FID model, Japan). Mean levels of heavy metals and TPH were higher in the study site compared to the control. The mean levels of heavy metals were $0.748 \mathrm{mg} / \mathrm{kg}(\mathrm{Pb}), 0.754 \mathrm{mg} / \mathrm{kg}(\mathrm{Cd}), 1.577 \mathrm{mg} / \mathrm{kg}(\mathrm{Ni}), 0.274 \mathrm{mg} / \mathrm{kg}(\mathrm{Cr}), 4.749 \mathrm{mg} / \mathrm{kg}(\mathrm{Fe}), 0.020$ $\mathrm{mg} / \mathrm{kg}$ (V), $0.103 \mathrm{mg} / \mathrm{kg}$ (Co), $0.181 \mathrm{mg} / \mathrm{kg}$ (As), $5.544 \mathrm{mg} / \mathrm{kg}(\mathrm{Mn})$, and $5.187 \mathrm{mg} / \mathrm{kg}$ (TPH). The heavy metals in the soil had an increasing sequence of $\mathrm{V}<\mathrm{Co}<\mathrm{As}<\mathrm{Cr}<\mathrm{Pb}<\mathrm{Cd}<\mathrm{Ni}<\mathrm{Fe}<\mathrm{Mn}$. The soil recorded the $\mathrm{Cd}, \mathrm{Cr}, \mathrm{Fe}, \mathrm{V}$, and As levels above the WHO permissible limits for soil. Ecological risk assessment revealed that $\mathrm{Cd}$ had the highest contamination $\left(\mathrm{C}_{\mathrm{f}}^{\mathrm{i}}\right)(91.47 \%)$ and ecological factor $\left(\mathrm{E}_{\mathrm{r}}^{\mathrm{i}}\right)(99.29 \%)$ in the soil, denoting that Cd contributed the most to the ecological instability and contamination of the soil. Co-relation, principal component analysis (PCA), and coefficient of variation (CV) revealed that $\mathrm{Pb}, \mathrm{Cd}, \mathrm{Ni}, \mathrm{Cr}, \mathrm{Fe}, \mathrm{V}, \mathrm{As}, \mathrm{Mn}$, and TPH were introduced into the soil through the crude oil spill (artificial sources), while Co originated from natural sources. A thorough clean-up of the spill site is therefore recommended to ecologically restore the soil. More of similar studies are required in other crude oil impacted soils in Niger Delta, Nigeria.
\end{abstract}

Keywords: ecological risk, source apportionment, heavy metals, hydrocarbon, oil spill, Ikot Ada Udo.

\section{INTRODUCTION}

Crude oil spillages from the Ibibio 1 oil well owned by Shell Petroleum Development Company (SPDC) first occurred in 1997, subsequently in 1999, 2004, and finally in 2007 [Udo, 2008]. A sabotage or mechanical fault in the facility (Ibibio 1 oil well) is predicted to be the cause of the 2007 spillage in Ikot Ada Udo, Nigeria. Only one barrel of crude oil per spill incident was released during the 1997, 1999, and 2004 spillage.
The largest oil spillage in this community occurred in 2007, releasing over 626 barrels of crude oil into farmlands [Udoh and Chukwu, 2014]. In 2008, SPDC carried-out a remediation exercise in an attempt to restore the environment back to normal, although studies indicates that the site is still unsafe [Udo, 2008; Udoh and Chukwu, 2014].

Refined Crude oil contains components like heavy metals, additives of dye, hydrocarbons, corrosion inhibitors, and antioxidants [Akporido, 2008; Albers, 1995]. It also contains fairly slight 
amounts of other components like sulfur, nitrogen, oxygen, salt, trace metals, and water [Osam, 2011]. Several oil spillage incidents occurred around the world in areas like Canadian marine waters, the Gulf of Mexico in 2010 [Serra-Sogas et al., 2008], and Prince Williams Sound, Alaska in 1989. Exxon Mobil reported that in 2014, several crude oil spill incidents in Nigeria led to the release of 9,100 barrels of hydrocarbons into water and soil environments. In 2003, Exxon Mobil reported that a supertanker referred to as Exxon Valdez ran aground at Prince William Sound, Alaska in the year 1989, thereby releasing over 250,000 crude oil barrels into the environment [Short, 2003].

Pipeline vandalization and oil spill have the capacity to contaminate the soil, thereby affecting plants and animals. Crude oil contains carcinogenic components which have the ability to bioaccumulate in the food chain. Due to the harmful contamination effect of the waste generated during crude oil exploration, it is pertinent to utilize the most efficient technology for the processing of crude oil and its products [Uzoekwe and Oshosanine, 2011].

Aquatic and terrestrial ecosystems receive industrial effluents and oil spills which causes environmental pollution. The fertility of soil is usually jeopardized by forest and farmland deforestation, which alters the properties of agricultural soils [Dambo, 2000]. Humans and the eco-system could be exposed to the heavy metals contamination from the consumption of crops cultivated in the soils contaminated by crude oil [Mclaughlin et al., 2000]. The ingestion of these heavy metals at unsafe levels could cause acute and chronic effects, thereby slowing the growth of biological organisms [Tietenberg, 2006].

Growth and proliferation of hydrocarbon utilizing microorganisms (HUM) such as bacteria and fungi are enhanced when huge amounts of hydrocarbon are released into soil and water environments. Coincidentally, the biodegradation of oil spills in our environments is made possible by hydrocarbon utilizing bacteria (HUB) and hydrocarbon utilizing fungi (HUF) [Dollah, 2004; Hamamura et al., 2006; Van Hamme et al., 2003]. However, the environment may not degrade the majority of the hydrocarbons by natural degradation. As a result, it is pertinent to utilize various biotechnologies during crude oil pollution remediation. Petroleum industries first applied biotechnological methods in remediating crude oil sites. The oil spill bioremediation methods use modern and natural environmental techniques to degrade crude oil in the environment without any environmental impacts [Hamamura et al., 2006].

Understanding the source of heavy metals accumulation in the environment, is a major step towards improving its control [Cloquet et al., 2006]. The source apportionment of heavy metals and total petroleum hydrocarbon (TPH) in the Ikot Ada Udo soil was carried out using coefficient of variation $(\mathrm{CV})$, co-relation, and principal component analysis (PCA). Though CV usually indicates the variation of heavy metals measured, they also effectively reveal the influence of human activities on the levels of heavy metals [Li et al., 2008]. CV and co-relation have been widely used to evaluate and characterize the source of heavy metals as well as hydrocarbon accumulation [Manta et al., 2002; Li et al., 2008; Wang et al., 2021]. A CV for any measured metal above $60 \%$ indicates human activities as the source of the metal, while a strong positive relationship between metals indicates same source of contamination [Li et al., 2008]. PCA reveals the loading potential of each metal across components [Pan et al, 2017]. Over the years, PCA and co-relation have been effectively used to apportion the sources of heavy metals in the environment worldwide [Chen et al., 2008; Li et al., 2009; Wang et al., 2021].

The present study sought to evaluate the ecological risk of heavy metals in the Ikot Ada Udo soil 12 years after it was partially remediated by SPDC. There are ongoing arguments by SPDC that the site was thoroughly remediated by their hired remediation expatriates in 2008. Furthermore, SPDC argue that any possible heavy metals contamination could be as a result of the community activities and not the oil spillage. To this end, this study targeted the potential sources of the present heavy metals contamination if any, while also assessing the suitability of the soil for normal growth and survival of biological organisms, since farming is the major source of livelihood of the Ikot Ada Udo indigenes. Although few research works have been carried-out on the heavy metals concentration in fish ponds, snails, and soil in Ikot Ada Udo [Udo, 2008; Udoh and Chukwu, 2014; Joseph et al., 2021], the information on the ecological risk of heavy metals from the crude oil spill in the soil of Ikot Ada Udo soil is non-existent, a huge gap this research aimed to bridge. Similarly, despite the consistent crude oil processing and spillage incidents in the Niger 
Delta region of Nigeria, there is a dearth of information on the ecological risk of heavy metals contamination from crude oil spillage in the soils from this area. Though natural remediation by micro-organisms is expected to be on-going in the site even after it was partially remediated by SPDC in 2008, it is pertinent to assess the ecological risk of the heavy metals released into the soil eco-system during the spillage incident, so as to reveal the safety of the soil towards the survival and growth of biological organisms. This study is the first of its kind targeting the sources of heavy metals contamination in an oil spill site from the Niger Delta region of Nigeria. Proper understanding of the ecological risk of crude oil on the study site soil will mark a major step towards adequate and prompt remediation of the site, so as to ensure the sustainability of biological organisms and the eco-system at large. The ecological risk of heavy metals from the crude oil spill on the soil of the study site was carried out using contamination factor $\left(\mathrm{C}_{\mathrm{f}}{ }^{\mathrm{i}}\right)$, ecological risk factor $\left(\mathrm{E}_{\mathrm{r}}{ }^{\mathrm{i}}\right)$, and risk index (RI). The study was generally aimed at evaluating the ecological risk of heavy metals from crude oil spill on the soil of Ikot Ada Udo, and also specifically addressed the following questions: 1) Does the soil from the study site have safe levels of heavy metals and TPH?, 2) Do the levels of heavy metals in the study site have ecological implications on the soil eco-system?, 3) Which of the studied heavy metals contributed more to the ecological risk of the soil eco-system?, and 4) Are the heavy metals in the study site soil from artificial (crude oil spillage) or natural sources?

\section{MATERIALS AND METHODS}

\section{Study area}

Ikot Ada Udo is sited between longitude $7^{\circ} 41$ ' 34.155" - $7^{\circ} 43$ ' 35.150" $\mathrm{E}$ and latitude $4^{\circ} 41^{\prime} 16.547^{\prime \prime}-4^{\circ} 49^{\prime} 16.637^{\prime \prime} \mathrm{N}$, with elevation of 32 meters (Fig. 1). The study site is located in the Niger Delta region of Nigeria. Annually, the area has a mean rainfall of $400 \mathrm{~mm}$ and with a humid tropical climate. The wet season starts in April and ends in November, whereas the dry season starts in November and ends in March; there is also a period of harmattan between December and January [Udo, 2008]. The study area is rich in tropical rain forest vegetation. Farming is the chief occupation of the indigenes, cultivating crops such as banana, maize, cassava, yams, water leaf, pepper, pumpkin, and plantain [Udoh and Chukwu, 2014]. The farmers in the community cultivate and harvest crops without the use of any form of organic and inorganic fertilizers.

\section{Sampling points}

The soil samples were collected from three sampling points (SP) of the study site. The sampling points were chosen at 50, 200, and 500 meters from the oil well and labelled as SP 1, SP 2, and SP 3, respectively. The control samples were collected at Ibagwa (Abak) about 10,000 meters from the study site. The control site is free from any sort of human activities, making it perfect for comparison with the levels of heavy metals in the impacted study site (Figure 1).

\section{Collection of soil samples}

Four composite soil samples were collected separately at a depth of $0-15 \mathrm{~cm}$ and $15-30 \mathrm{~cm}$ during each sampling occasion using a hand-held auger. The samples were collected into pre-treated polyethylene bags and labeled accordingly once every month over one year (from May 2018 to April, 2019). Through-out the study, a total of 48 composite soil samples were collected separately and analyzed for heavy metals and hydrocarbon levels. After each sample collection, the auger was sterilized with methylated spirit to avoid cross-contamination. Immediately after collection, the samples were preserved in ice, then taken to the Environmental Laboratory of the Ministry of Science and Technology, Uyo for heavy metals and TPH analysis. The soil samples were dried and passed through a $2 \mathrm{~mm}$ sieve before chemical analysis.

\section{Chemical analysis of soil}

In the laboratory, the ice chest preserved soil samples were allowed to normalize and assume the normal temperature of the laboratory. Then, $5 \mathrm{~g}$ of dried sediment samples were put in a $100 \mathrm{~mL}$ Teflon beaker and then $10 \mathrm{~mL}$ of pure concentrated $\mathrm{HNO}_{3}$ (Merck) was added. In a hot plate, the sample was then heated for 0.5 , $0.5,0.5$, and 2 hours to $100,150,210$, and 280 ${ }^{\circ} \mathrm{C}$ using a DK-20 heating digester. Afterwards, $2 \mathrm{~mL}$ of $1 \mathrm{~N} \mathrm{HNO}_{3}$ was added to the residue and the solution was allowed to evaporate in the hot 


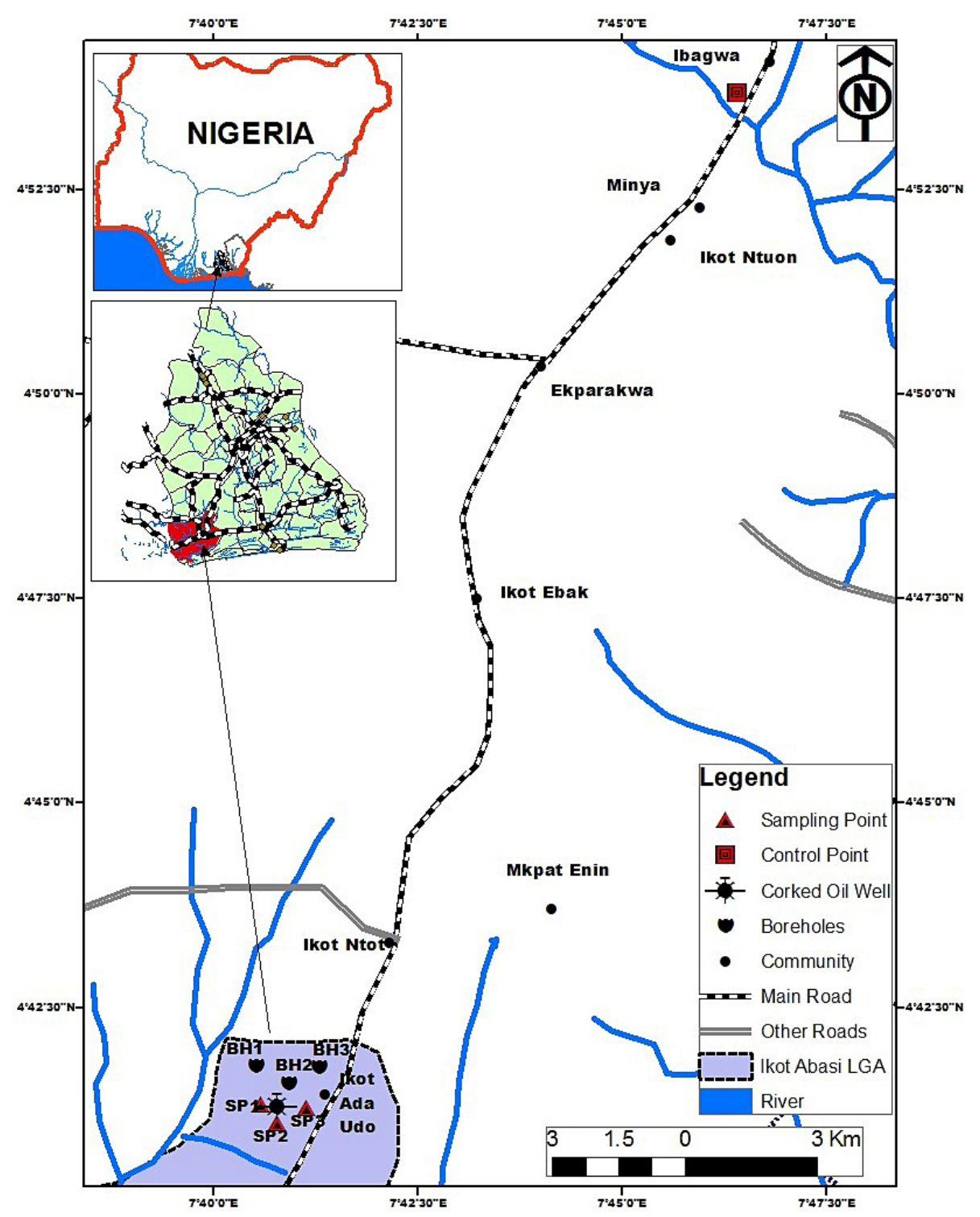

Figure 1. Map showing the corked Ibibio 1 oil well and the sampling points in Ikot Ada Udo Source: Adapted from Google Earth Pro, 2015. Scale: $1 \mathrm{~cm}=3 \mathrm{~km}$

plate until a complete digestion was achieved, after which $10 \mathrm{~mL}$ of $1 \mathrm{~N} \mathrm{HNO}_{3}$ was added. A 0.45-1 m nitrocellulose membrane filter was then used to filter the solution [Alam et al., 2002]. The calibration curve technique was used to determine the quantification of metals and the working standards were prepared using the calibration standards of individual metal (Merck, Germany). The standard solution concentrations were plotted against their respective absorbance reading to obtain the calibration curve. Heavy metals were determined using inductively coupled plasma atomic emission spectrometry (ICP-AES, Yobin Yvon JY-24) to the nearest milligram per kilogram $(\mathrm{mg} / \mathrm{kg})$. The detection limit is taken as the least analytical signal which qualitatively differs at a specified confidence level from the background signal [Kackstaetter and Heinrichs, 1997]. The limits of detection were $\mathrm{Pb}$ (0.053), $\mathrm{Cd}(0.018), \mathrm{Ni}(0.025), \mathrm{Cr}$ (0.076), Fe (0.105), V (0.016), Co (0.120), As (0.013), and Mn (0.014).

In the ICP-AES analysis, the detection limits of the measured elements were defined as the concentration values that correspond to their absorbance value, numerically equal to three times the standard deviation of 10 replicate blank measurements. The standard reference materials of soil used was SRM-2710. These analyses were replicated and the reference materials showed good accuracy, with recovery rates of metals between $92 \%$ and $104 \%$. 
TPH in soil was carried out as described by Adewuyi and Olowu [2012]; Cortes et al. [2012]; Alinnor et al. [2014]. Five grams of anhydrous $\mathrm{Na}_{2} \mathrm{SO}_{4}$ was introduced to the sample of soil and then mixed. After stirring, $30 \mathrm{~mL}$ of extractable Dichloromethane (DCM) solvent was then added to the mixture, and then shaken for five to six hours using an electrical shaker at room temperature, before filtering. The total petroleum hydrocarbon (TPH) of the soil was then analyzed to the nearest $\mathrm{mg} / \mathrm{kg}$ using Agilent 6890N Gas Chromatography - Flame Ionization Detector (GC-FID model, Japan).

\section{Potential ecological risk assessment}

Potential ecological risk (PER) is a diagnostic technique used to evaluate the implications of contaminants on the suitability of the soil for survival and growth of biological organisms. This was evaluated using contamination factor $\left(C_{f}{ }^{i}\right)$, ecological risk factor $\left(E_{r}{ }^{i}\right)$, and risk index $(R I)$ as described by Hakanson $[1980,1988]$ and was interpreted according to Table 1.

\section{Contamination factor}

Contamination factor $C_{f}{ }^{i}$ is described as the ratio of the levels of heavy metals to the background value of heavy metals in Nigeria as shown in equation (1).

$$
C_{f}^{i}=C_{i} / C^{i}
$$

where: $C_{i}$ - concentration of heavy metals in soil, $C^{i}$ - background values of heavy metals.

The background values heavy metals and TPH in soil were taken from DPR [2002] as follows: $29 \mathrm{mg} / \mathrm{kg}$ (As), $0.8 \mathrm{mg} / \mathrm{kg}$ (Cd), $100 \mathrm{mg} / \mathrm{kg}$ $(\mathrm{Cr}), 20 \mathrm{mg} / \mathrm{kg}(\mathrm{Co}), 85 \mathrm{mg} / \mathrm{kg}(\mathrm{Pb}), 712 \mathrm{mg} / \mathrm{kg}$ (Mn), $35 \mathrm{mg} / \mathrm{kg}(\mathrm{Ni})$, and $50 \mathrm{mg} / \mathrm{kg}$ (TPH).

\section{Ecological risk factor}

Ecological risk factor $E_{r}{ }^{i}$ is a product of the contamination factor of heavy metals and the toxic response factor of heavy metals, as shown in equation (2).

$$
E_{r}{ }^{i}=C_{f}{ }^{i} \times T_{r}^{i}
$$

where: $T_{r}^{i}$ - toxic response factor of metals.

The $T_{r}^{i}$ was taken as $\mathrm{Pb}(5), \mathrm{Ni}(5), \mathrm{Cd}(30)$, $\mathrm{Cr}$ (2), As (10), and V (2).

\section{Risk index}

The risk index $R I$ was determined from the summation of the ecological risk factor of all metals, according to equation (3).

$$
R I=\sum E_{r}^{1}+E_{r}^{2}+E_{r}^{3}+E_{r}^{n}
$$

\section{Statistical analysis}

The data collected passed the normality test. The heavy metals data in the soil from the sampling points of the study area was subjected to descriptive statistics (Ranges, mean \pm standard deviation). One-way analysis of variance (ANOVA) was used to determine the significant differences between the TPH, heavy metals levels in soil of each sampling points compared to the control. All analyses were carried out using GraphPad prism 5 at a significance level of 0.05 . Co-relation statistics was carried out on the obtained data to reveal the possible relationship of metals, while $\mathrm{CV}$ and PCA were carried out to determine the source of heavy metals and TPH in the soil of the study

\begin{tabular}{|c|c|c|c|c|c|}
\hline \multicolumn{2}{|c|}{ Contamination factor } & \multicolumn{2}{|c|}{ Ecological risk factor } & \multicolumn{2}{|c|}{ Ecological risk index } \\
\hline $\begin{array}{c}\text { Contamination } \\
\text { factor }\left(C_{f}{ }^{i}\right)\end{array}$ & $\begin{array}{c}\text { Degree of } \\
\text { contamination }\end{array}$ & $\begin{array}{l}\text { Potential ecological } \\
\text { risk factor }\left(E_{r}^{i}\right)\end{array}$ & $\begin{array}{c}\text { Degree of } \\
\text { ecological risk factor } \\
\end{array}$ & $\begin{array}{c}\text { Ecological risk index } \\
(\mathrm{IR})\end{array}$ & $\begin{array}{c}\text { Degree of } \\
\text { ecological risk }\end{array}$ \\
\hline $\mathrm{C}_{\mathrm{f}}{ }^{\mathrm{i}}<1$ & Low & $\mathrm{E}_{\mathrm{r}}<40$ & Low & IR $<150$ & Low \\
\hline $1 \leq C_{f}{ }^{i}<3$ & Moderate & $40 \leq E_{r}<80$ & Moderate & $150 \leq \mathrm{IR}<300$ & Moderate \\
\hline $3 \leq \mathrm{C}_{\mathrm{f}}{ }^{\mathrm{i}}<6$ & considerable & $80 \leq E_{r}<160$ & High & $300 \leq \mathrm{IR}<600$ & Severe \\
\hline \multirow[t]{2}{*}{$\mathrm{C}_{\mathrm{f}}{ }^{i} \geq 6$} & Very high & $160 \leq E_{r} \leq 320$ & Higher & $R \geq 600$ & Serious \\
\hline & & $E_{r} \geq 320$ & Serious & & \\
\hline
\end{tabular}
site using SPSS version 20.

Table 1. Ecological risk of heavy metals in the soil from Ikot Ada Udo (Hakanson, 1980) 


\section{RESULTS}

\section{Heavy metals and TPH levels in soil}

The mean and ranges of heavy metal and TPH levels in the soil from the control site (Abak) and Ikot Ada Udo (study site) are shown in Table 2. The heavy metals and TPH levels varied between sampling points. The concentrations of lead $(\mathrm{Pb})$, cadmium $(\mathrm{Cd})$, nickel $(\mathrm{Ni})$, chromium $(\mathrm{Cr})$, iron $(\mathrm{Fe})$, arsenic (As), manganese $(\mathrm{Mn})$, and TPH in each sampling point (SP 1, 2 and 3) of Ikot Ada Udo were significantly higher $(\mathrm{p}<0.05)$, while the cobalt $(\mathrm{Co})$ level was insignificantly higher $(p>0.05)$ compared to control. Mean vanadium (V) concentration in sampling point 1 was significantly higher than the control $(\mathrm{p}<0.05)$, while those of sampling points 2 and 3 were insignificantly higher than the control $(\mathrm{p}>0.05)$. The mean $\mathrm{Cd}$, $\mathrm{Cr}, \mathrm{Fe}, \mathrm{V}$, and As concentrations in the soil samples from Ikot Ada Udo were above the WHO and SQG acceptable limits. The concentrations of $\mathrm{Cd}, \mathrm{Cr}, \mathrm{Fe}, \mathrm{V}$, and As were 1.3, 2.74, 2.49, 2 , and 1.8 times higher than the WHO acceptable limits, respectively. The sequence of heavy metals concentrations in Ikot Ada Udo was $\mathrm{V}<\mathrm{Co}<\mathrm{As}<\mathrm{Cr}<\mathrm{Pb}<\mathrm{Cd}<\mathrm{Ni}<\mathrm{Fe}<\mathrm{Mn}$ (Table 2).

\section{Ecological risk of heavy metals}

The results of the ecological risk of heavy metals and TPH in soil from the study site is shown in Table 3. The highest $\mathrm{C}_{\mathrm{f}}^{\mathrm{i}}$ in the soil was observed in $\mathrm{Cd}(1.942)$, followed by TPH $(0.1037)$, and $\mathrm{Ni}(0.045)$ and contributed $91.47 \%, 4.88 \%$, and $2.12 \%$ of the contamination respectively (Table 3 ).

Table 2. Heavy metals and TPH levels in the soil of the Ikot Ada Udo

\begin{tabular}{|c|c|c|c|c|c|c|c|c|}
\hline \multirow{2}{*}{$\mathrm{S} / \mathrm{N}$} & \multirow{2}{*}{$\begin{array}{l}\text { Metals } \\
(\mathrm{mg} / \mathrm{kg})\end{array}$} & \multirow{2}{*}{ Control (Abak) } & \multicolumn{4}{|c|}{ Soil samples from Ikot Ada Udo } & \multirow{2}{*}{$\begin{array}{l}\text { WHO } \\
\text { [1996] }\end{array}$} & \multirow{2}{*}{$\begin{array}{l}\text { SQG } \\
\text { [2010] }\end{array}$} \\
\hline & & & SP 1 & SP 2 & SP 3 & Mean & & \\
\hline 1. & $\mathrm{~Pb}$ & $\begin{array}{c}0.008 \pm 0.007^{a} \\
(0.001-0.02)\end{array}$ & $\begin{array}{c}0.987 \pm 0.458^{\mathrm{b}} \\
(0.001-1.40)\end{array}$ & $\begin{array}{c}0.712 \pm 0.452^{b} \\
(0.001-1.24)\end{array}$ & $\begin{array}{c}0.526 \pm 0.485^{b} \\
(0.001-1.33)\end{array}$ & $\begin{array}{c}0.748 \pm 0.489 \\
(0.001-1.40)\end{array}$ & $<20$ & - \\
\hline 2. & $\mathrm{Cd}$ & $\begin{array}{l}0.048 \pm 0.106^{a} \\
(0.010-0.041)\end{array}$ & $\begin{array}{c}0.852 \pm 0.390^{\mathrm{b}} \\
(0.36-1.24)\end{array}$ & $\begin{array}{c}0.758 \pm 0.478^{b} \\
(0.20-1.21) \\
\end{array}$ & $\begin{array}{c}0.652 \pm 0.422^{\mathrm{b}} \\
(0.21-1.02) \\
\end{array}$ & $\begin{array}{c}\mathbf{0 . 7 5 4} \pm \mathbf{0 . 4 6 3} \\
(0.33-0.73) \\
\end{array}$ & 0.58 & 0.6 \\
\hline 3. & $\mathrm{Ni}$ & $\begin{array}{c}0.095 \pm 0.321^{\mathrm{a}} \\
(0.032-0.152)\end{array}$ & $\begin{array}{c}1.995 \pm 0.805^{b} \\
(1.30-2.60)\end{array}$ & $\begin{array}{c}1.338 \pm 0.731^{\mathrm{b}} \\
(0.58-0.86)\end{array}$ & $\begin{array}{c}1.398 \pm 0.835^{b} \\
(0.98-2.01)\end{array}$ & $\begin{array}{c}1.577 \pm 0.814 \\
(0.58-2.60)\end{array}$ & - & 18 \\
\hline 4. & $\mathrm{Cr}$ & $\begin{array}{c}0.012 \pm 0.005^{\mathrm{a}} \\
(0.002-0.01)\end{array}$ & $\begin{array}{c}0.398 \pm 0.130^{\mathrm{b}} \\
(0.32-0.46)\end{array}$ & $\begin{array}{c}0.232 \pm 0.181^{\mathrm{b}} \\
(0.11-0.35)\end{array}$ & $\begin{array}{c}0.193 \pm 0.180^{\mathrm{b}} \\
(0.10-0.32)\end{array}$ & $\begin{array}{c}\mathbf{0 . 2 7 4} \pm \mathbf{0 . 1 4 4} \\
(0.10-0.46)\end{array}$ & 0.10 & - \\
\hline 5. & $\mathrm{Fe}$ & $\begin{array}{c}1.543 \pm 0.410^{\mathrm{a}} \\
(0.99-2.35)\end{array}$ & $\begin{array}{c}5.710 \pm 2.739^{\mathrm{b}} \\
(4.52-6.82)\end{array}$ & $\begin{array}{c}4.390 \pm 2.636^{b} \\
(3.26-5.22)\end{array}$ & $\begin{array}{c}4.145 \pm 0.204^{\mathrm{b}} \\
(3.00-5.70)\end{array}$ & $\begin{array}{c}4.749 \pm 2.398 \\
(3.00-6.82)\end{array}$ & 1.90 & - \\
\hline 6. & V & $\begin{array}{c}0.002 \pm 0.001^{a} \\
(0.001-0.01)\end{array}$ & $\begin{array}{c}0.036 \pm 0.025^{b} \\
(0.003-0.06)\end{array}$ & $\begin{array}{c}0.014 \pm 0.013^{a} \\
(0.001-0.04)\end{array}$ & $\begin{array}{c}0.009 \pm 0.013^{a} \\
(0.001-0.04)\end{array}$ & $\begin{array}{c}\mathbf{0 . 0 2 0} \pm \mathbf{0 . 0 1 5} \\
(0.001-0.06)\end{array}$ & 0.01 & - \\
\hline 7. & Co & $\begin{array}{c}0.017 \pm 0.034^{\mathrm{a}} \\
(0.001-0.12)\end{array}$ & $\begin{array}{c}0.106 \pm 0.018^{\mathrm{a}} \\
(0.01-0.18)\end{array}$ & $\begin{array}{c}0.051 \pm 0.024^{\mathrm{a}} \\
(0.01-0.13)\end{array}$ & $\begin{array}{c}0.152 \pm 0.013^{\mathrm{a}} \\
(0.006-1.20)\end{array}$ & $\begin{array}{c}0.103 \pm 0.016 \\
(0.006-1.20)\end{array}$ & - & - \\
\hline 8. & As & $\begin{array}{c}0.011 \pm 0.007^{a} \\
(0.001-0.02)\end{array}$ & $\begin{array}{c}0.267 \pm 0.156^{\mathrm{b}} \\
(0.21-0.32)\end{array}$ & $\begin{array}{c}0.141 \pm 0.052^{b} \\
(0.10-0.26)\end{array}$ & $\begin{array}{c}0.134 \pm 0.132^{b} \\
(0.10-0.20)\end{array}$ & $\begin{array}{c}\mathbf{0 . 1 8 1} \pm \mathbf{0 . 1 2 0} \\
(0.10-0.32) \\
\end{array}$ & 0.10 & - \\
\hline 9 & $\mathrm{Mn}$ & $\begin{array}{c}2.322 \pm 1.166^{\mathrm{a}} \\
(1.29-4.35)\end{array}$ & $\begin{array}{c}6.683 \pm 3.311^{\mathrm{b}} \\
(4.32-8.66)\end{array}$ & $\begin{array}{c}5.006 \pm 3.209^{\mathrm{b}} \\
(3.06-7.40)\end{array}$ & $\begin{array}{c}4.944 \pm 3.300^{\mathrm{b}} \\
(2.56-8.21)\end{array}$ & $\begin{array}{c}5.544 \pm 3.283 \\
(2.56-8.66)\end{array}$ & 9.30 & 10 \\
\hline 10. & $\mathrm{TPH}$ & $\begin{array}{c}0.167 \pm 0.216^{\mathrm{a}} \\
(0.001-0.61)\end{array}$ & $\begin{array}{c}7.164 \pm 2.108^{b} \\
(3.02-9.96)\end{array}$ & $\begin{array}{c}7.327 \pm 3.988^{b} \\
(5.76-9.40)\end{array}$ & $\begin{array}{c}6.087 \pm 3.845^{b} \\
(4.51-7.82)\end{array}$ & $\begin{array}{c}5.187 \pm 3.201 \\
(3.02-3.62)\end{array}$ & 10 & 100 \\
\hline
\end{tabular}

Note: Values in Mean \pm Standard deviation; Ranges in Parenthesis ( ); SP 1 - Sampling point 1; TPH - Total petroleum hydrocarbon; SQG- Sediment quality guideline. Values with different superscript in each sampling point compared to the control differed significantly ( $<<0.05$ ); Bold mean metal values in Ikot Ada Udo are unsafe.

Table 3. Ecological risk of heavy metals in soil of the study site

\begin{tabular}{|c|c|c|c|}
\hline Metals & Contamination factor $\left(\mathrm{C}_{\mathrm{f}}^{\mathrm{i}}\right)$ & Ecological risk factor $\left(\mathrm{E}_{\mathrm{r}}^{\mathrm{i}}\right)$ & Risk index RI \\
\hline $\mathrm{Pb}$ & 0.0088 & 0.044 & \\
\hline $\mathrm{Cd}$ & $\mathbf{1 . 9 4 2}$ & $\mathbf{4 8 . 2 6 0}$ & \\
\hline $\mathrm{Ni}$ & 0.045 & 0.225 & 48.604 \\
\hline $\mathrm{Cr}$ & 0.00274 & 0.00548 & \\
\hline $\mathrm{Co}$ & 0.00678 & - & \\
\hline $\mathrm{As}$ & 0.0062 & 0.062 & \\
\hline $\mathrm{Mn}$ & 0.00778 & 0.00778 & \\
\hline $\mathrm{TPH}$ & 0.1037 & - & \\
\hline
\end{tabular}

Note: N/B the $\mathrm{C}_{\mathrm{f}}^{\mathrm{i}}$ of $\mathrm{Fe}$ and $\mathrm{V}$ were not calculated because their DPR background value are not available; $\mathrm{E}_{\mathrm{r}}^{\mathrm{i}}$ of $\mathrm{Co}$ and $\mathrm{TPH}$ were not calculated because their toxic response factor is not available; Bold $\mathrm{C}_{\mathrm{f}}^{\mathrm{i}}$ and $\mathrm{E}_{\mathrm{r}}^{\mathrm{i}}$ values indicate ecological risk. 
The $\mathrm{C}_{\mathrm{f}}^{\mathrm{i}}$ of $\mathrm{Cd}$ in the study site soil fell within the 1 $\leq \mathrm{C}_{\mathrm{f}}{ }^{\mathrm{i}}<3$ category as shown in Table 1 .

The highest $\mathrm{E}_{\mathrm{r}}^{\mathrm{i}}$ in the soil was observed in $\mathrm{Cd}$ (48.260), followed by $\mathrm{Ni}(0.225)$, and As (0.062), accounting for $99.29 \%, 0.46 \%$, and $0.12 \%$ ecological risk of these metals in the soil (Table 3 ). The $\mathrm{E}_{\mathrm{r}}^{\mathrm{i}}$ of $\mathrm{Cd}$ in the study site soil fell within the $40 \leq \mathrm{E}_{\mathrm{r}}<80$ category. The RI value of the soil was within the IR $<150$ category as shown in Table 1 .

\section{Sources of heavy metals and TPH in soil}

The results of the $\mathrm{CV}$ of heavy metals in the study area soil is shown in Table 4, while the relationship between each metal in the soil is shown in Table 5. The PCA showing the relationship and sources of heavy metals in the soil is shown in Figure 2. The $\mathrm{CV}$ of $\mathrm{Pb}, \mathrm{Cd}, \mathrm{Ni}, \mathrm{Cr}, \mathrm{Fe}, \mathrm{V}, \mathrm{As}$, $\mathrm{Mn}$, and TPH were above $60 \%$. The highest CV was recorded for $\mathrm{V}(75.00 \%)$, followed by As (66.29\%), $\mathrm{Pb}$ (65.37\%), and then TPH (61.71\%) (Table 4). Pb had a strong positive relationship with $\mathrm{Cd}, \mathrm{Ni}, \mathrm{Cr}, \mathrm{Fe}, \mathrm{V}, \mathrm{As}, \mathrm{Mn}$, and TPH (Table 5). Principal component 1 (PC 1) had high positive loading values of $0.99,0.96,0.93,0.99,0.99$, 0.97, 0.97, and 0.72 for $\mathrm{Pb}, \mathrm{Cd}, \mathrm{Ni}, \mathrm{Cr}, \mathrm{Fe}, \mathrm{V}$, As, Mn, and TPH respectively, resulting in a total variance of $80.77 \%$. PC 2 had a high positive loading value of 0.97 for $\mathrm{Co}$, resulting in a total variance of $19.224 \%$ (Fig. 2).

Table 4. Coefficient of variation and mean concentration of heavy metals in soil from the study site

\begin{tabular}{|c|c|c|c|}
\hline Parameters & Mean value & Standard deviation & CV \% \\
\hline $\mathrm{Pb}$ & 0.748 & 0.489 & $\mathbf{6 5 . 3 7}$ \\
\hline $\mathrm{Cd}$ & 0.754 & 0.463 & $\mathbf{6 1 . 4 0}$ \\
\hline $\mathrm{Ni}$ & 1.577 & 0.814 & $\mathbf{5 1 . 6 1}$ \\
\hline $\mathrm{Cr}$ & 0.274 & 0.144 & $\mathbf{5 2 . 5 5}$ \\
\hline $\mathrm{Fe}$ & 4.749 & 2.398 & $\mathbf{5 0 . 4 9}$ \\
\hline $\mathrm{V}$ & 0.02 & 0.015 & 15.53 \\
\hline $\mathrm{Co}$ & 0.103 & 0.016 & $\mathbf{6 6 . 2 9}$ \\
\hline $\mathrm{As}$ & 0.181 & 0.120 & $\mathbf{5 9 . 2 1}$ \\
\hline $\mathrm{Mn}$ & 5.544 & 3.283 & $\mathbf{6 1 . 7 1}$ \\
\hline $\mathrm{TPH}$ & 5.187 & 3.201 & \\
\hline
\end{tabular}

Note: N/B Bold CV value indicates artificial source.

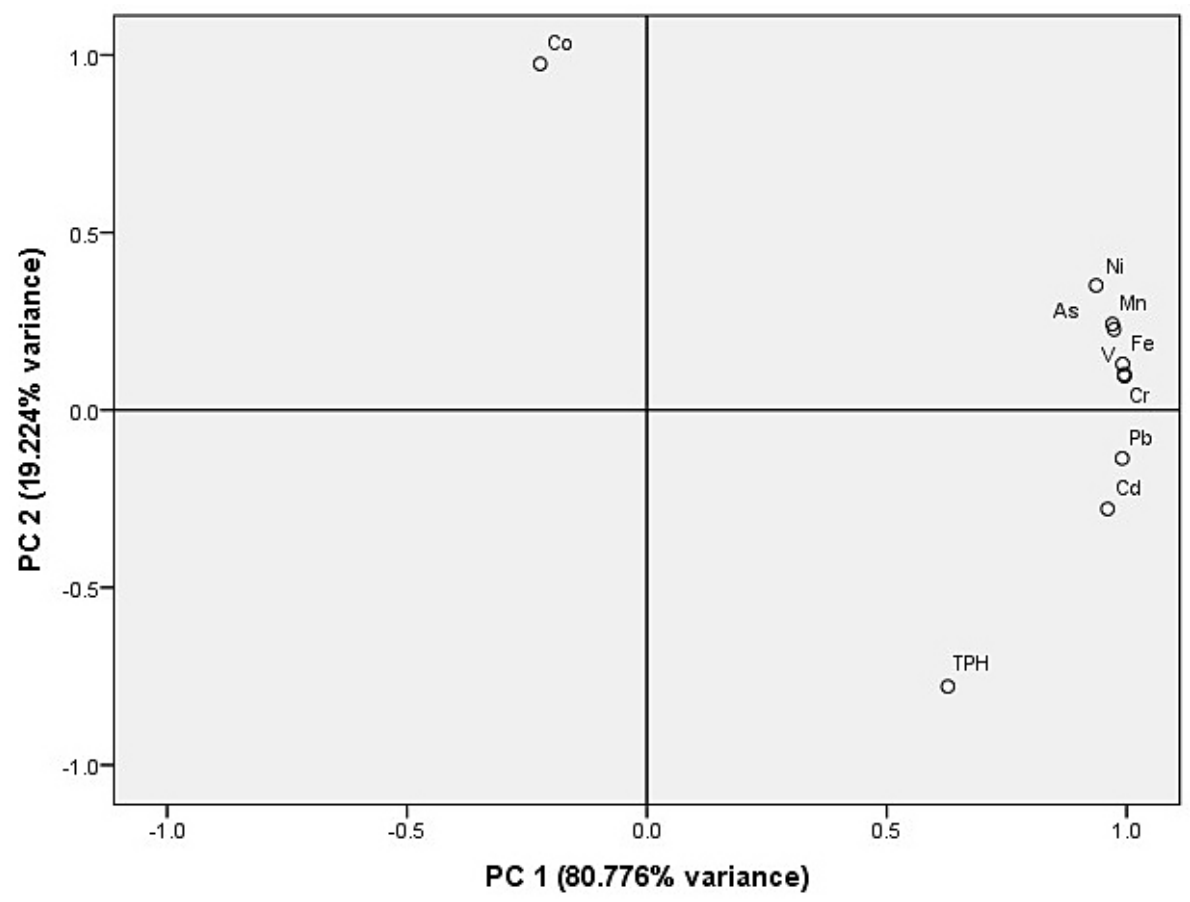

Figure 2. Principal component analysis of heavy metals in the soil 
Table 5. Correlation matrix of heavy metals in soil from the study site

\begin{tabular}{|c|c|c|c|c|c|c|c|c|c|c|}
\hline Element & $\mathrm{Pb}$ & $\mathrm{Cd}$ & $\mathrm{Ni}$ & $\mathrm{Cr}$ & $\mathrm{Fe}$ & $\mathrm{V}$ & $\mathrm{Co}$ & $\mathrm{As}$ & $\mathrm{Mn}$ & $\mathrm{TPH}$ \\
\hline $\mathrm{Pb}$ & 1.00 & 0.98 & 0.88 & 0.97 & 0.96 & 0.97 & -0.35 & 0.93 & 0.92 & 0.72 \\
\hline $\mathrm{Cd}$ & 0.98 & 1.00 & 0.80 & 0.92 & 0.91 & 0.92 & -0.48 & 0.87 & 0.86 & 0.82 \\
\hline $\mathrm{Ni}$ & 0.88 & 0.80 & 1.00 & 0.96 & 0.97 & 0.96 & 0.13 & 0.99 & 0.99 & 0.31 \\
\hline $\mathrm{Cr}$ & 0.97 & 0.92 & 0.96 & 1.00 & 0.99 & 0.99 & -0.12 & 0.99 & 0.98 & 0.55 \\
\hline $\mathrm{Fe}$ & 0.96 & 0.91 & 0.97 & 0.99 & 1.00 & 0.99 & -0.09 & 0.99 & 0.99 & 0.52 \\
\hline $\mathrm{V}$ & 0.97 & 0.92 & 0.96 & 0.98 & 0.99 & 1.00 & -0.12 & 0.99 & 0.99 & 0.54 \\
\hline $\mathrm{Co}$ & -0.35 & -0.48 & 0.13 & -0.12 & -0.09 & -0.12 & 1.00 & 0.01 & 0.02 & -0.89 \\
\hline $\mathrm{As}$ & 0.93 & 0.87 & 0.99 & 0.99 & 0.99 & 0.99 & 0.01 & 1.00 & 0.99 & 0.43 \\
\hline $\mathrm{Mn}$ & 0.92 & 0.86 & 0.99 & 0.98 & 0.99 & 0.99 & 0.02 & 0.99 & 1.00 & 0.42 \\
\hline $\mathrm{TPH}$ & 0.72 & 0.82 & 0.31 & 0.55 & 0.52 & 0.54 & -0.89 & 0.43 & 0.02 & 1.00 \\
\hline
\end{tabular}

\section{DISCUSSION}

Contaminants such as hydrocarbons, antioxidants, and heavy metals are introduced into the soil by crude oil spillage [Albers, 1995; Akporido, 2008]. Given that oil pollution is accompanied by major soil nutrient imbalances and obvious alteration in chemical, physical, and microbiological properties of soil [Udoh and Chukwu, 2014], the obtained findings raise concerns on the potential ecological impact of heavy metals in a poorly remediated Ikot Ada Udo soil while also affirming the potential source of heavy metals and TPH. Furthermore, heavy metals and TPH are rarely broken down, but bio-magnify as they ascend the trophic

The ecological implications of heavy metals in the soil of the study site were investigated for the first time and also revealed the heavy metal sources. The obtained findings revealed variations in the accumulation of metals and TPH between the sampling points soil (study site), and recorded higher values of metals and TPH for each sampling point compared to the control. This result corroborated with a previous study on the toxic metals pollution in impacted soils using soil invertebrates [Udousoro et al., 2015]. The higher concentration of the studied contaminants in the study site compared to the control could be because crude oil spill contains hydrocarbons and heavy metals, which were potentially released into the environment, thereby increasing the level of the contaminants in the soil [Albers, 1995; Akporido, 2008].

The mean levels of $\mathrm{Pb}, \mathrm{Cd}, \mathrm{Ni}, \mathrm{Cr}, \mathrm{Mn}$, and TPH in soil for the conducted study were all lower than those of the studies on the oil spill impact in Ikot Ada Udo, Akwa Ibom State [Udo, 2008]; crude oil impacts in the soils of Niger Delta, Nigeria [Iwegbue, 2011]. The mean Ni and Mn concentration in soil for this study were lower, while the mean Fe and TPH levels were higher than those of the study on heavy metals and hydrocarbon levels in oil-polluted agriculture zone of Gokana, Ogoni land, Rivers State [Nwaichi et al., 2014] . Furthermore, the mean $\mathrm{Pb}, \mathrm{Fe}$, and TPH in this study were lower while the mean $\mathrm{Cd}$ and Mn concentrations were higher than those of the study on the post-impact of crude oil spill on the soil properties of Ikot Abasi, Niger Delta, Nigeria [Udoh and Chukwu, 2014]. The heavy metals trend of $\mathrm{V}<\mathrm{Co}<\mathrm{As}<\mathrm{Cr}<\mathrm{Pb}<\mathrm{Cd}<\mathrm{Ni}<\mathrm{Fe}<\mathrm{Mn}$ observed in the present study did not corroborate with the heavy metals trend reported by Iwegbue [2011]. The difference in the level of heavy metals, TPH, and trend between the present study and the other studies compared could be because the extent of contamination of soil and residual oil impact on soil quality varies depending on the time duration of productivity of oil well [Wang and Feng, 2009]. Furthermore, the extent of environmental pollution [Nakamura et al., 2005], solubility of soil and chemical form precipitation [Udousoro et al., 2015], and distance of the sampling point from the corked Ibibio oil well could also be the reason for the difference.

The concentrations of $\mathrm{Cd}, \mathrm{Cr}, \mathrm{Fe}, \mathrm{V}$, and As were above the WHO limit for soil by 1.3, 2.74, $2.49,2$, and 1.8 times. These metals build up in the soil, affect the soil ecology, and are in turn ingested by humans via the consumption of edible crawling animals and crops cultivated in the impacted soil. Consequently, the ingestion of unsafe levels of $\mathrm{Cd}$ from the consumption of edible crawling animals and crops cultivated in the impacted soil could cause health challenges such 
as kidney disorders and itai itai disease [WHO, 2007]. Furthermore, the ingestion of $\mathrm{Cr}$ at unacceptable levels could cause nose irritation and ulcer, running nose, asthma, cough, liver and kidney damage, and irritation of the skin [WHO, 2007]. Though Fe is highly essential to the human body, its ingestion above the normal level required for the normal functioning of the body may cause stomach and intestinal side effects like nausea and vomiting [WHO, 2007]. Unacceptable levels of $\mathrm{V}$ could cause eyes, upper respiratory and skin irritation, skin, continuous trachea bronchi inflammation, systemic poisoning, and pulmonary edema [WHO, 2007]. Moreover, the ingestion of As above the normal levels could cause cancer of the skin, lungs, bladder, and kidney to the population in the future [WHO, 2007]. Though the other studied contaminants were within the safe levels, they could still build up in the environment over time, bio-magnify across trophic levels, and become toxic in the near future.

Ecological risk measures $\left(\mathrm{C}_{\mathrm{f}}^{\mathrm{i}}, \mathrm{E}_{\mathrm{r}}^{\mathrm{i}}\right.$, and IR) are a diagnostic technique used to evaluate the implications of contaminants on the suitability of soil for the survival and growth of biological organisms. This technique has been extensively used to describe the ecological impact of heavy metals in soil [Xu et al., 2016, Ghorbani et al., 2020]. In this study, this technique was also used to great effect to evaluate the ecological implications of heavy metals in the soil from a poorly remediated crude oil site. From the obtained findings, it was observed that $\mathrm{Cd}$ had the highest $\mathrm{C}_{\mathrm{f}}^{\mathrm{i}}$ in the soil, followed by $\mathrm{TPH}$, and $\mathrm{Ni}$, contributing $91.47 \%, 4.88 \%$, and $2.12 \%$ of the contamination respectively. This denotes that $\mathrm{Cd}$ was the major contributor to the soil contamination in the study site because of its high percentage contribution. Similarly, TPH and Ni contributed to the contamination and ecological imbalance of the soil though to a lower extent. These metals finds their way to plant tissues, crawling animals, and humans, causing health challenges such as kidney disorders, itai itai disease, intestinal side effect, and cancer when these contaminants are ingested [WHO, 2007]. Despite the insignificant percentage contribution of $\mathrm{Pb}, \mathrm{Cr}, \mathrm{Co}, \mathrm{As}$, and $\mathrm{Mn}$ to the soil contamination, they could still build up and bio-magnify in higher trophic level organisms thereby posing health dangers in the foreseeable future. These contaminants could generally make the soil ecologically unstable, thus possibly affecting the crop productivity within the study site
[Tietenberg, 2006]. The $\mathrm{C}_{\mathrm{f}}^{\mathrm{i}}$ of $\mathrm{Cd}$ in the study site soil fell within the $1 \leq \mathrm{C}_{\mathrm{f}}{ }^{\mathrm{i}}<3$ category which illustrates that the $\mathrm{Cd}$ caused a moderate contamination of the soil, which spells serious danger to the soil ecology and humans at large because they are very toxic even at low concentrations, causing nutrient imbalance in the soil and kidney disorders, as well as itai itai disease to humans over time [WHO, 2007]. Just as in the case of the $\mathrm{C}_{\mathrm{f}}^{\mathrm{i}}$, $\mathrm{Cd}$ was the chief ecological risk factor, contributing to $99.29 \%$ of the ecological imbalance of the soil, followed by Ni $(0.46 \%)$, and As $(0.12 \%)$. The ecological implications of the unacceptable levels of Cd have already been previously demonstrated. Though Ni, As, and the other heavy metals made insignificant contribution to the ecological imbalance of the soil, they have the capacity to bio-magnify and become toxic over time, while also making the soil ecologically unstable [Tietenberg, 2006]. This could affect the crop productivity within the study site over time. The $\mathrm{E}_{\mathrm{r}}^{\mathrm{i}}$ of $\mathrm{Cd}$ in the study site soil fell within the $40 \leq$ $\mathrm{E}_{\mathrm{r}}<80$ category, indicating a moderate degree of ecological risk, while the RI was within the IR < 150 category and indicating a low degree of ecological risk. Nevertheless, the $\mathrm{E}_{\mathrm{r}}^{\mathrm{i}}$ of $\mathrm{Cd}$ and low IR value of the studied metals could still create significant ecological instability and poor nutrient quality within the soil which may affect crop productivity [Tietenberg, 2006].

In this study, the sources of heavy metals in the soil were apportioned using co-relation, $\mathrm{CV}$, and PCA. Co-relation and CV have been successfully used worldwide by renowned researchers for the apportionment of heavy metal sources [Manta et al., 2002; Li et al., 2008; Chen et al., 2008; Li et al., 2009; Wang et al., 2021]. The conducted study revealed that $\mathrm{Pb}$ had a strong positive relationship with $\mathrm{Cd}, \mathrm{Ni}, \mathrm{Cr}, \mathrm{Fe}, \mathrm{V}, \mathrm{As}, \mathrm{Mn}$, and $\mathrm{TPH}$, indicating that the aforementioned accumulation of metals in the soil came from the same source. In order to fully identify the source of the metals, CV and PCA were carried out. The $\mathrm{CV}$ of all the studied contaminants were above $60 \%$ except for Co $(15.53 \%)$, indicating a wide variability of these metals $(\mathrm{Pb}, \mathrm{Cd}, \mathrm{Ni}, \mathrm{Cr}, \mathrm{Fe}, \mathrm{V}$, $\mathrm{As}, \mathrm{Mn}$, and TPH) and huge influence of human activities on their accumulation in the soil [ $\mathrm{Li}$ et al., 2008]. Specifically, this reveals that the $\mathrm{Pb}$, $\mathrm{Cd}, \mathrm{Ni}, \mathrm{Cr}, \mathrm{Fe}, \mathrm{V}, \mathrm{As}, \mathrm{Mn}$, and TPH in the study site soil were introduced by the crude oil spillage (artificial sources), while Co was introduced from natural sources. Crude oil spill is stated as 
the artificial source of contamination because no other noticeable serious activities take place in the study site other than farming (without the use of manure), and also because crude oil contains heavy metals and hydrocarbons [Albers, 1995; Akporido, 2008]. Co occurs naturally in the environment from the weathering of soil and rocks, soil erosion, and wind dust [Khan and Khathi, 2014]. This observation aligns with the result of the co-relation statistic which predicted that the $\mathrm{Pb}, \mathrm{Cd}, \mathrm{Ni}, \mathrm{Cr}, \mathrm{Fe}, \mathrm{V}, \mathrm{As}, \mathrm{Mn}$, and TPH accumulation in the soil came from similar sources. Furthermore, PCA revealed high positive loading values for $\mathrm{Pb}, \mathrm{Cd}, \mathrm{Ni}, \mathrm{Cr}, \mathrm{Fe}, \mathrm{V}, \mathrm{As}, \mathrm{Mn}$, and TPH in PC 1 resulting in a total variance of $80.77 \%$ and a high positive loading value for Co in PC 2 resulting in a $19.22 \%$ variance. The high positive loading values of $\mathrm{Pb}, \mathrm{Cd}, \mathrm{Ni}, \mathrm{Cr}, \mathrm{Fe}, \mathrm{V}, \mathrm{As}, \mathrm{Mn}$, and TPH in PC 1 further confirms the accuracy of the co-relation result, further proving that these metals are related and were introduced into the soil from the same source. Similarly, the $80.77 \%$ total variance in PC 1 was higher than $60 \%$, indicating that the high loading of $\mathrm{Pb}, \mathrm{Cd}, \mathrm{Ni}, \mathrm{Cr}$, $\mathrm{Fe}, \mathrm{V}, \mathrm{As}, \mathrm{Mn}$, and TPH in the soil came from the crude oil spill (human activities) since no other serious activities take place in the study site, as reveled by indigenes of the community. PC 2 revealed a high positive loading value for Co with a resulting $19.22 \%$ total variance, which confirms the reliability of $\mathrm{CV}$ results towards the apportionment of heavy metal sources. This $19.22 \%$ total variance in PC 2 is lower than $60 \%$, denoting that $\mathrm{Co}$ loading were introduced into the soil via natural sources. The obtained result also revealed highest $\mathrm{CV}$ value for $\mathrm{V}$, followed by $\mathrm{As}, \mathrm{Pb}$, and $\mathrm{TPH}$, indicating that $\mathrm{V}$ was the most widely variable and was the most influenced contaminant by the oil spillage.

\section{CONCLUSIONS}

The obtained findings raise concerns on the potential ecological impact of heavy metals in the soil, while also affirming the potential source of heavy metals and TPH. The ecological implications of heavy metals in the soil impacted by crude oil in the Niger Delta region of Nigeria were investigated for the first time and also revealed the sources of contaminants. Higher values of metals and TPH were recorded for each sampling point of the study site compared to the control. The soil had unsafe levels of $\mathrm{Cd}, \mathrm{Cr}, \mathrm{Fe}$, $\mathrm{V}$, and As in the soil. The ecological risk evaluation $\left(\mathrm{C}_{\mathrm{f}}^{\mathrm{i}}, \mathrm{E}_{\mathrm{r}}^{\mathrm{i}}\right)$ revealed $\mathrm{Cd}$ as the major contributor to the contamination and ecological risk of the soil, resulting in moderate contamination, soil instability, poor nutrient and ecological imbalance of the soil, and potentially poor crop productivity. The IR revealed low degree of ecological risk in the soil. Co-relation, PCA, and CV revealed that $\mathrm{Pb}, \mathrm{Cd}, \mathrm{Ni}, \mathrm{Cr}, \mathrm{Fe}, \mathrm{V}, \mathrm{As}, \mathrm{Mn}$, and TPH were introduced into the soil through the crude oil spill (artificial sources), while Co originated from natural sources. There is a need to conduct further studies on the ecological risk of heavy metals and TPH from crude oil spill on soils in other areas of Niger Delta, Nigeria.

\section{Acknowledgements}

We appreciate Mr. Pascal for carrying out the laboratory analysis of heavy metals and TPH in the soil samples. Overall, we appreciate God almighty for the privilege to successfully carry out this research.

\section{REFERENCES}

1. Adewuyi G.O., Olowu R.A. 2012. Assessment of oil and grease, total petroleum hydrocarbons, and some heavy metals in surface and groundwater within the vicinity of NNPC oil depot in Apata, Ibadan Metropolis, Nigeria. Int. J. Res. Resour., 13, 166-174.

2. Akporido S.O. 2008. An assessment of water, sediment, and soil pollution arising from crude oil spillages in the vicinity of Esi River, Western Niger Delta. University of Ibadan.

3. Alam M.G.M., Tanaka A., Allinson G., Laurenson L.J.B., Stagnitti F., Snow E. 2002. A comparison of trace element concentrations in cultured and wild carp (Cyprinus carpio) of Lake Kasumigaura, Japan. Ecotoxicol. Environ. Saf., 53, 348-354.

4. Albers P.H. 1995. Petroleum and individual polycyclic Aromatic hydrocarbons., in: Handbook of Ecotoxicology. Lewis, London, 330-355.

5. Alinnor I.J., Ogukwe C.E., Nwagbo N.C. 2014. Characteristic level of total petroleum hydrocarbon in soil and groundwater of oil impacted area in the Niger Delta Region, Nigeria. J. Environ. Earth Sci., 4, 188-194.

6. Chen T., Liu X.M., Zhu M.Z., Zhao K.I., Wu J.J., Xu J.M., Huang P.M. 2008. Identification of trace element sources and associated risk assessment in vegetable soils in of the urban-rural transitional area 
of Hangzhou, China. Environ. Pollut., 151, 67-78.

7. Cloquet C., Carignan J., Libourel G., Sterckeman T., Perdrix E. 2006. Tracing source pollution in soils using cadmium and lead isotopes. Environ. Sci. Technol., 40, 2525-2530.

8. Cortes J.E., Suspes A., Roa S., Gonzalez C., Castro H.E. 2012. Total petroleum hydrocarbons by gas chromatography in Colombian waters and soils. Am. J. Environ. Sci., 8, 396-402.

9. Dambo W.B. 2000. Ecotoxicology of heavy metals and petroleum-related compounds on the mangrove oysters (Crasstrea rhizophorea) from the Lower Botany Estuary Port-Harcourt. Africa Linkpress, 26-34.

10. Dollah S.A. 2004. Bioremediation of petroleum hydrocarbon polluted soil: Potentials, principles, and applications. J. Environ. Manag. Educ., 1, 171-180.

11. Ghorbani M.R., Ghanavati N., Babaenejad T., Nazarpour A., Payandeh K. 2020. Assessment of the potential ecological and human health risks of heavy metals in Ahvaz oil field, Iran. PLoS One, 15(11), e0242703. https://doi.org/10.1371/journal. pone. 0242703

12. DPR. 2002. Environmental guidelines and standards for the petroleum industry in Nigeria (revised edition).

13. Hamamura N., Olson S., Ward D., Inskeep W. 2006. Microbial population dynamics associated with crude-oil biodegradation in diverse soils. Appl. Environ. Microbiol., 72, 6316-6324.

14. Iwegbue C.M. 2011. Assessment of heavy metal speciation in soils impacted with crude oil in the Niger Delta, Nigeria. Chem. Speciat. Bioavailab., 23, 6-15.

15. Joseph A.P., Iwok E.B., Ekanem S. 2021. Public health threats of heavy metals due to the consumption of Achachatina marginata (African Giant Land Snail ) from a partially remediated site in Ikot Ada Udo, Akwa Ibom State, South-South. Environ. Pollut. 271, 1-7.

16. Håkanson L. 1980. An ecological risk index for aquatic pollution control: A sedimentological approach. Water Res., 14, 975-1001. DOI: 10.1016/0043-1354(80)90143-8.

17. Håkanson L. 1988. Metal Monitoring in Coastal Environments., in: Metals in Coastal Environments of Latin America, Seeliger U., Lacerda L.D, Patchineelam S.R (Eds). Springer-Verlag, 240-257. DOI:10.1007/978-3-642-71483-2_21.

18. Li F.Q., Pan H.M., Ye W., Zhu L.D., Wang Z.G. 2008. Specificity of heavy metals pollution and and the ecological hazard in urban dust. J. Anhui. Agricult. Sci., 36(6), 2495-2498.

19. Li J.L., He M., Han W., Gu Y.F. 2009. Analysis and assessment of heavy metal sources in the coastal soils developed from alluvial deposits using multivariate statistical methods. J. Hazard. Mater., 164, 976-981.

20. Kackstaetter U.R. \& Heinrichs G. 1997. Validity of lowcost laboratory geochemistry for environmental applications. Water Air Soil Pollut., 95, 119-131.

21. Khan A.B., Kathi B. 2014. Evaluation of heavy metal and total petroleum hydrocarbon contamination of roadside surface soil. Int. J. Environ. Sci. Technol., 11(8), 2259-2270.

22. Manta D.S., Angelone M., Bellanca A., Neri R., Sprovieri M. 2002. Heavy metals urban soils: a case study from the city of Palermo (Sicily), Italy. Sci. Total Environ., 300(1-3), 229-243.

23. Mclaughlin M.J., Zarcinas B.A., Stevens D.P., Cook N. 2000. Soil testing for heavy metals. Commun. Soil Sci. Plant Anal., 31, 1661-1700.

24. Nakamura K., Taira J., Higa Y. 2005. Internal elements of the millipede, Chamberlinius haulienensis Wang (Polydesmida: Paradoxosomatidae). Appl. Entomol. Zool. 40, 283-288.

25. Nwaichi E.O., Wegwu M.O., Nwosu U.L. 2014. Distribution of selected carcinogenic hydrocarbon and heavy metals in an oil-polluted agriculture zone. Environ. Monit. Assess. 186, 8697-8706.

26. Osam M.U. 2011. Evaluation of the selected wild type legumes in remediation of crude oil contaminated agricultural soils. University of Port Harcourt.

27. Pan H.Y., Lu X.W., Lei K. 2017. A comprehensive analysis of heavy metals in urban road dust of Xi'an, China: contamination, source apportionment and spatial distribution. Sci Total Environ., 609, 1361-1369.

28. Serra-Sogas N.P.D., O’hara R., Canessa P., Keller S., Pelot R. 2008. Visualization of spatial patterns and temporal trends for aerial surveillance of illegal oil discharges in Western Canadian marine waters. Mar. Pollut. Bull., 56, 825-833.

29. Short J. 2003. Long-term effects of crude oil on developing fish: Lessons from the Exxon Valdez oil spill. Energy Sources.

30. SQG. 2010. Sediment quality guidelines of soil. Virginia Department of Environmental Quality, USA.

31. Suleimanov A.Y. 1995. Conditions of waste fluid accumulation at petrochemical and processing enterprise prevention of their harm to water bodies. Meditsina Tr. Promyswe Nnaia Ekol., 12, 31-36.

32. Tietenberg T. 2006. Economics of pollution control, in: Environmental and Natural Resource Economics. Pearson, Boston, 15.

33. Udo E.J. 2008. Environmental impacts of the oil spill at Ikot Ada Udo in Akwa Ibom State, Nigeria. PAM Scientific Laboratories, Uyo, Nigeria, for Environmental Rights Action/Friends of the Earth.

34. Udoh B.T., Chukwu E.D. 2014. Post-impact assessment of oil pollution on some soil characteristics 
in Ikot Abasi, Niger Delta region, Nigeria. J. Biol. Agric. Healthc., 4, 111-119.

35. Udousoro I.I., Umoren I.U., Izuagie J.M. 2015. Soil invertebrates as bio-monitors of toxic metal pollution in impacted soils. Curr. world Environ., 10, 367-385.

36. Uzoekwe S.A., Oshosanine F.A. 2011. The effect of refinery and petrochemical effluent on water quality of Ubeji creek Warri, Southern Nigeria. Ethiop. J. Environ. Stud. Manag., 4, 107-116.

37. Van Hamme J.D., Singh A., Ward O.P. 2003. Recent advances in petroleum microbiology. Microbiol. Molecular Biol. Rev, 67, 503-549.

38. Wang X. \& Feng J. 2009. Effects of crude oil redial on soil chemical properties in oil sites, Momgage Wetland, and China. Environ. Monit. Assess., 161, 271-280.
39. Wang H., Zhao Y., Walker T.R., Wang Y., Luo Q., Wu H. 2021. Distribution characteristics, chemical speciation and human health risk assessment of metals in surface dust in Shenyang City, China. Appl. Geochem., 131, 105031. https://doi.org/10.1016/j. apgeochem.2021.105031

40. WHO. 1996. Permissible limits of heavy metals/physico-chemical properties in soil. Geneva, Switzerland.

41. WHO. 2007. Water, soil, and organisms for pharmaceutical use. Quality assurance of pharmaceuticals: A compendium of guidelines and related materials. 2nd updated edition. Geneva.

42. Xu J., Wang H., Liu Y., Ma M., Zhang T., Zheng X., Zong M. 2016. Ecological risk assessment of heavy metals in soils surrounding oil waste disposal areas. Environ. Monit. Assess., 188, 125. https://doi. org/10.1007/s10661-016-5093-x. 